\title{
5. DIAMOND CORING SYSTEM PHASE IIB ${ }^{1}$
}

\author{
J.E. Briggs, ${ }^{2}$ R.P. Lawrence, ${ }^{2}$ and D.H. Reudelhuber ${ }^{2}$
}

\section{INTRODUCTION AND BACKGROUND}

Throughout the Deep Sea Drilling Project (DSDP) and the Ocean Drilling Program (ODP), there has been great scientific interest in investigating and sampling mid-ocean ridges worldwide. Due to the highly fractured and unstable nature of the young basalts, however, attempts to core before the diamond coring system (DCS) was developed yielded only limited amounts of core from shallow holes. Prior to DCS, coring was attempted with roller-cone core bits only. The crushing action typical of a roller-cone bit tended to further fracture the already fractured formations, most of the time causing core jams at the throat of the bit. Core recovery using this method was typically less than $10 \%$ in these formations. Instability of any resulting hole was increased by the crushing action of the bit, and the instability typically eliminated forward progress of the hole depth. Drilling or coring under these conditions has been likened to attempting to drill in a jar of marbles. If any advance is made with the bit, the hole immediately fills in as soon the bit is retracted off bottom. This problem, coupled with little or no core recovery, makes the use of conventional ODP coring techniques very ineffective.

The concept of using the DCS for coring these hard, fractured, abrasive rocks grew from knowledge of the successes in the mining industry in coring fractured and highly unstable crystalline rock formations. High-speed rotation of small-diameter diamond coring bits in these types of formations was commonly found to yield core recoveries of $90 \%$ or more. Hole size is significantly smaller, 4 in. typically as opposed to $9-7 / 8$ in. for an ODP roller-cone core bit. The smaller hole size has been repeatedly shown to improve the stability of the cored hole. Additionally, the cutting action of the diamond bits is totally different in that the rock is gouged and cut. Roller-cone bits, on the other hand, crush the rock and cause it to fail in compression.

ODP therefore developed a coring system that would use these coring advantages in deep water from a dynamically positioned drillship. The coring system was directly adapted from the designs of those of the mining industry. A totally new dimension was needed, however: the ship's heave motion had to be eliminated at the diamond bit in order to apply the mining coring technology properly and to core successfully. DCS development first began in 1988. A prototype system was deployed successfully in 1989 on Leg 124E. The system was used again on Leg 132 in 1990, when it recovered significant amounts of core. This report covers the third use of the DCS during Leg 142 at an axial summit caldera on the East Pacific Rise.

\section{PHASE I DEVELOPMENT: LEG 124E}

The purpose of Phase I development was to demonstrate that a mining system could be deployed from a floating vessel. During a two-week period in January 1989, the prototype system was evaluated. This version of the system was designed to remove the effects of heave and maintain accurate weight on bit, in water depths up to $2000 \mathrm{~m}$ with a maximum residual heave of \pm 6 in. The residual heave results from the inefficiency of the primary drill-string compensator on the vessel, normally used for conventional coring operations with

\footnotetext{
${ }^{1}$ Storms, M.A., Batiza, R., et al., 1993. Proc. ODP, Init. Repts., 142: College Station, TX (Ocean Drilling Program). U.S.A.

Ocean Drilling Program, Texas A\&M University, College Station, TX 77845-9547,
}

the relatively large coring bits and 5 - or $5-1 / 2$-in. drill pipe. The prototype DCS incorporated a hydraulic top drive and a hydraulic feed and compensation system controlled by a computer. The system was suspended from the 400 -ton primary heave compensator in the derrick. Residual heave was then measured with an accelerometer mounted directly on the DCS platform. This signal in turn was fed into the secondary heave compensator computer to create the drive for a servo valve. The servo valve then created the necessary drive for a hydraulic cylinder from which the DCS top drive, tubing, and bit were suspended (see Fig. 1).

The DCS drill string was deployed within the existing 5-1/2-in. drill pipe used by ODP during normal operations. A 3-1/2-in. tubing string, equipped with Hydril premium threaded connections, was used to rotate the diamond bit. Five cores were successfully cut in clay and silty clay. The limited amount of time allotted to testing of the DCS during Leg 124E did not allow use of the coring system in fractured basalt. However, there was sufficient use of the DCS to prove that high-speed diamond coring could be done from a floating vessel. The quality of the recovered cores was encouraging and led to further development of the system (for details, see Harding, Storms, et al., 1990).

\section{PHASE II DEVELOPMENT: LEG 132}

Phase II development expanded on the capabilities of the Phase I equipment. The first significant design change was to increase the system's depth capability. The new specification called for a depth capability of up to $4500 \mathrm{~m}$, with residual heaves of up to $\pm 12 \mathrm{in}$. To accomplish this, the feed and compensation systems were modified. The Phase I compensator was entirely an active system and employed only one cylinder, located above the top drive in the center of the mast structure (see Fig. 2). The Phase II hydraulics were designed such that compensation was a combination of active and passive methods, and employed two cylinders for handling the load of the top drive and tubing (see Fig. 3 for a schematic of the Phase II DCS).

The second major design change was to employ an electric top drive. This change made more hydraulic horsepower (hp) available for use in secondary heave compensation and auxiliary hydraulic functions (i.e., wireline winch, tuggers, etc.). It also enabled the DCS to core at much higher torques and speeds under even greater loads. The top drive is powered by an 800 -hp direct-current (DC) traction motor and it is equipped with a gearbox and high-speed swivel. The API rating of the top drive is 650 tons, which far exceeds any future growth. The gearbox ratio is $1.5: 1$, resulting in a maximum rated torque of $8000 \mathrm{ft}-\mathrm{lb}$ at a shaft speed of $520 \mathrm{rpm}$.

With the change in the top drive, a new control system for the top drive had to be designed. The controls were designed to yield more precise speed and torque control with improved performance and efficiency. The new top drive made use of DC power available from the existing shipboard silicon controlled rectifier (SCR) system. The existing control electronics on the ship were modified by incorporating closed-loop motor control, resulting in very accurate top-drive shaft speed, independent of torque.

Slimhole coring uses far lower drilling fluid-flow rates than normal rotary coring. Flow rates for slimhole coring range between 10 to 70 gallons per minute (gpm) vs. 210 to $350 \mathrm{gpm}$ for conventional rotary methods. To adapt the existing large mud pumps on the ship to this type of coring (i.e., operating at speeds far below normal), closed-loop motor controls were also incorporated here. New controls 


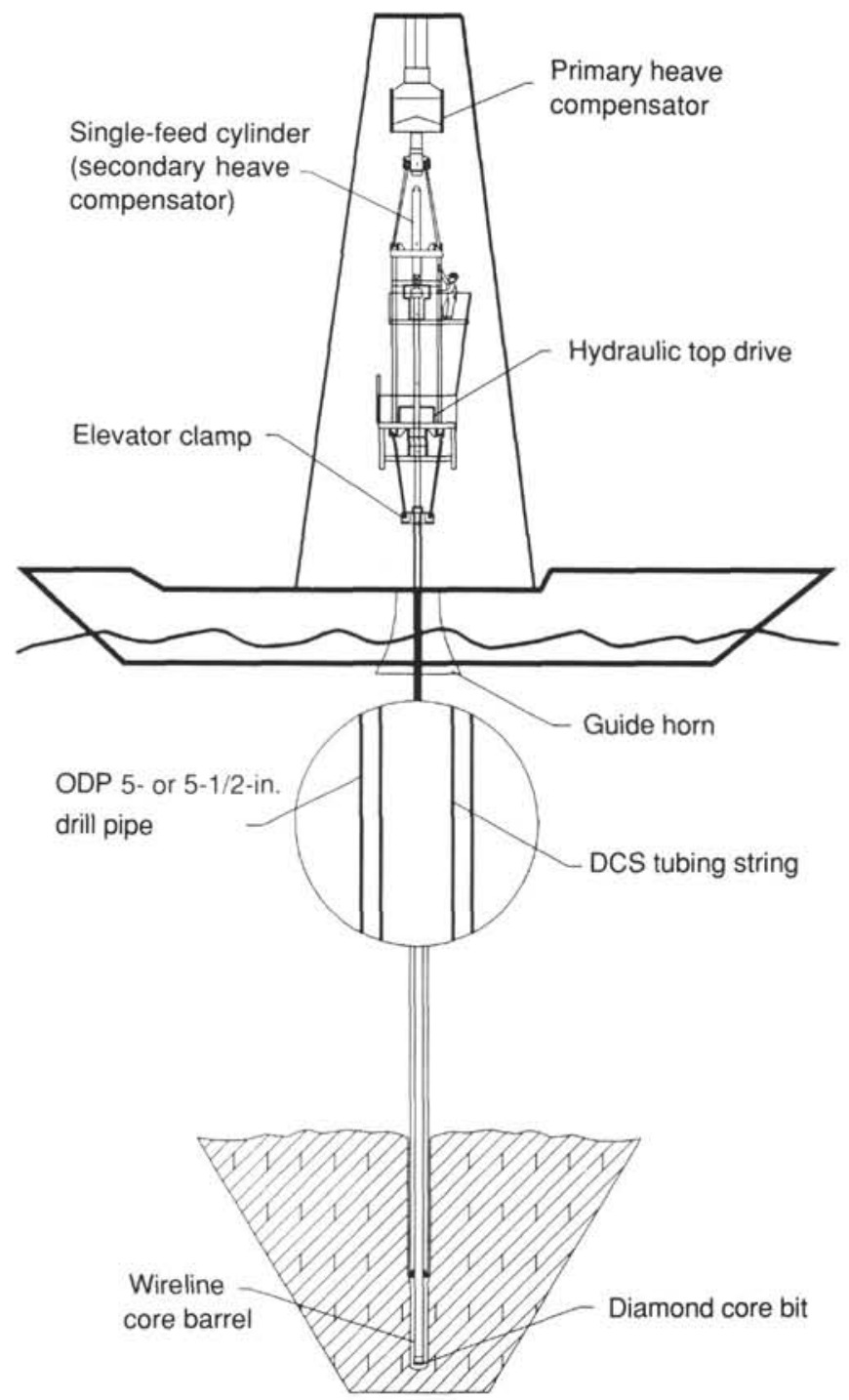

Figure 1. Diamond coring system, Phase I (2000 m depth capacity).

were installed in the mud-pump SCR control racks. These controls allow the pump to be operated at very slow speeds using closed-loop feedback, the same as is used on the DCS top drive. One of the mud pumps was equipped with 4-in. liners to further decrease the rate of flow at any given speed. Both pumps are Oilwell A1700-PT triplex units driven by two 800 -hp motors each, and they are normally equipped with $6-1 / 2$-in. liners for rotary coring. The 4 -in. liners produce 1.9 gallons per pump revolution. The new controls allowed the pumps to operate smoothly at $3 \mathrm{rpm} / 6 \mathrm{gpm}$.

The secondary heave compensator was totally reworked from the Phase I system. The original system proved to be neither rugged enough nor compact enough for the DCS application. The Phase II system was developed around the Intel 80196 Embedded Controller, a microprocessor specially designed for control functions and associated control hardware. The computer system was reduced to a two-board configuration and was installed in the existing control panel instead of in a stand-alone housing. The hardware was programmed in $\mathrm{C}$ language like its predecessor. This system is run in a passive/active configuration such that the computer drives the rod side of the feed cylinders (only). This is referred to as three-way servo configuration. This method requires less hydraulic horsepower than would a fully active system (see Fig. 4).
Details of Phase II equipment development are not covered here. Specific information on Phase II equipment development can be found in Section 3 of the Initial Reports volume for Leg 132 (Storms, Natland, et al., 1991).

\section{PHASE IIB DEVELOPMENT: LEG 142}

There were few major changes made to the DCS during the time between Phases II and IIB. The changes were mainly in the area of safety and reliability. The safety systems and secondary controls were thoroughly reworked for Phase IIB. The work was performed at Dreco in Rosenberg, Texas, between June and November 1991.

\section{Shock Cylinder System}

The DCS mast/platform assembly was outfitted with new shock cylinders. During Leg 132, it was discovered that the existing shock cylinder system had nearly reached its load capacity. This meant that any further significant weight addition to the platform would require increasing the capacity of the shock cylinder systems. The original shock cylinder system utilized four cylinders, each sized at 2-1/2 in. (piston) $\times 1-1 / 4$ in. (rod). These were replaced with two 5 -in. $\times 2$ $1 / 2$-in. cylinders, much stronger than the original cylinders. In addition, large piping and larger relief valves were installed to handle the increased flow rates associated with the larger cylinders. Relief valves, set to a pressure slightly higher than that resulting from the static weight of the platform, relieve the fluid pressure that builds up on the rod side of the shock cylinders if the platform is accelerated upward. That is, if there is a main drill-string failure, the rod-side pressure will rise above the relief valve setting, and the relief valve will open, preventing the platform from accelerating at the same rate as the mast. When the mast eventually stops, check valves open to allow the cylinders to retract. This in turn prevents the platform from decelerating at the same rate as the mast. The platform accelerations and decelerations are thus made to be much smaller than those of the mast.

The DCS platform is suspended from the DCS mast via the shock cylinders, and they are the only support for the platform. New secondary (emergency) platform stops were fabricated also. The stops act as a backup system if the cylinders were to fail in tension, thus preventing the platform from sliding off the bottom end of the mast.

\section{Shock Cylinder Drop Tests}

In order to better model the response of the new pressure-relief valves and cylinders used in the shock cylinder system, "drop" tests were performed. A single shock cylinder and hydraulic circuit were installed in a specially designed test fixture. A known "static" weight was then suspended from the shock cylinder. This load represented the platform static load normally suspended from the mast on the two shock cylinders. Next, a dynamic load, representing the force due to acceleration of the platform during a "slingshot" event, was abruptly applied to the shock cylinder by dropping another weight (the "dynamic" weight) that was also attached to the cylinder. Measured data included cylinder pressure and stroke vs. time. The test was then repeated at various static and dynamic loads.

Results of the tests were used to calibrate a computer program that modeled the dynamic behavior of the shock cylinder system. The tests also helped to confirm pressure integrity of all hydraulic components.

\section{Mast/Platform Slingshot Tests}

Full-scale testing of the shock cylinder system required a rather large test setup. A derrick from a large land-drilling rig was used to suspend the mast/platform assembly. The mast was connected to the derrick crown beams with a large 16-in. air cylinder. The lower end 


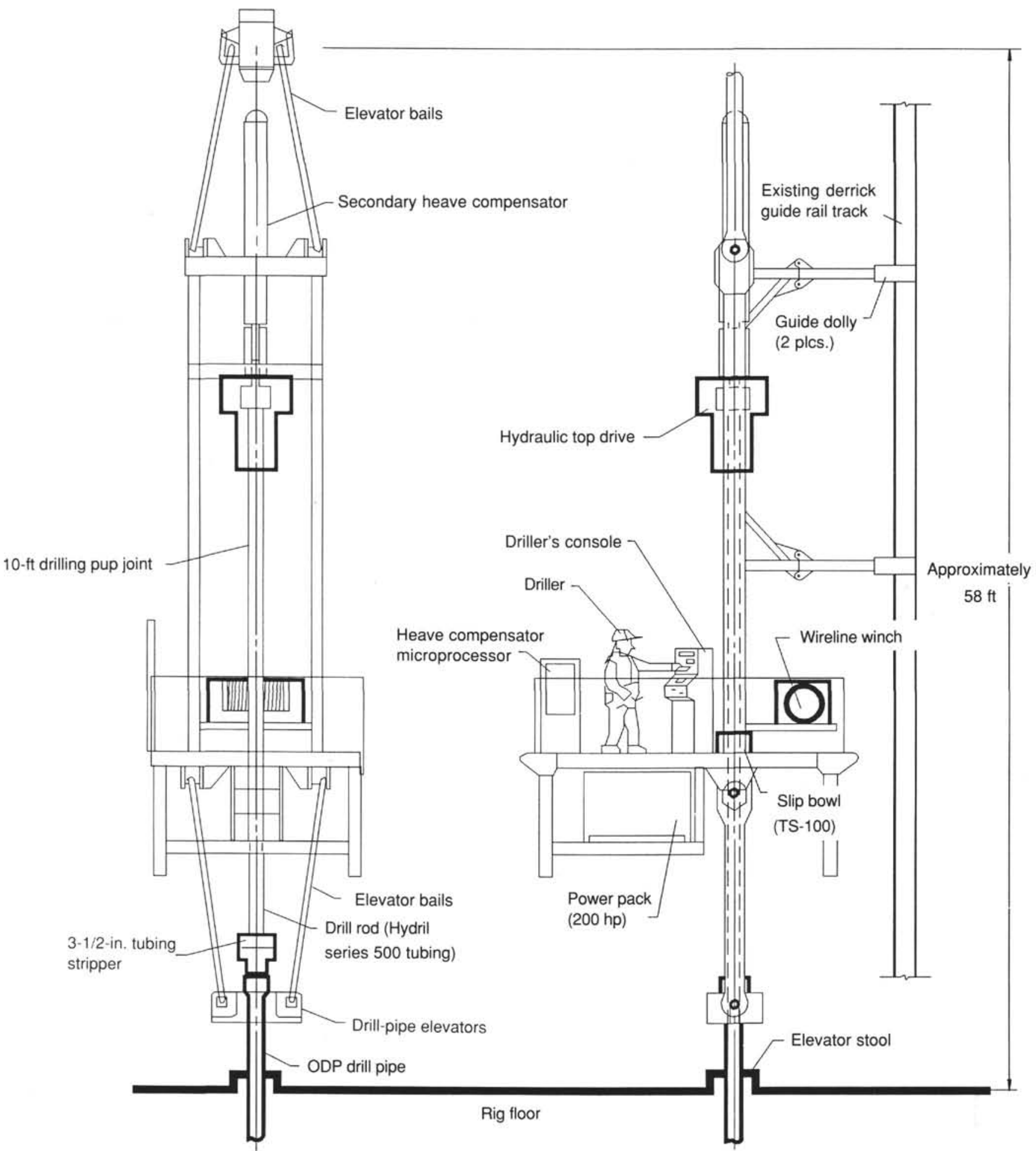

Figure 2. DCS platform configuration.

of the mast was made fast to the derrick substructure, using an 8-in.-diameter pipe.

Test sequences consisted of tensioning the mast by applying a known air pressure to the air cylinder. The 8 -in. pipe was then explosively severed to simulate a sudden loss of drill-string weight (as would occur if there was a main drill-string failure during actual DCS operations).
Measured data included mast displacement from Earth, platformto-mast displacement, platform acceleration, and individual shock cylinder pressures (rod side of cylinder). The data were analyzed to ensure that the shock cylinders provided the proper amount of isolation from large mast accelerations. Such potentially large accelerations would occur in the unlikely event of a significant loss of the main drill string. 


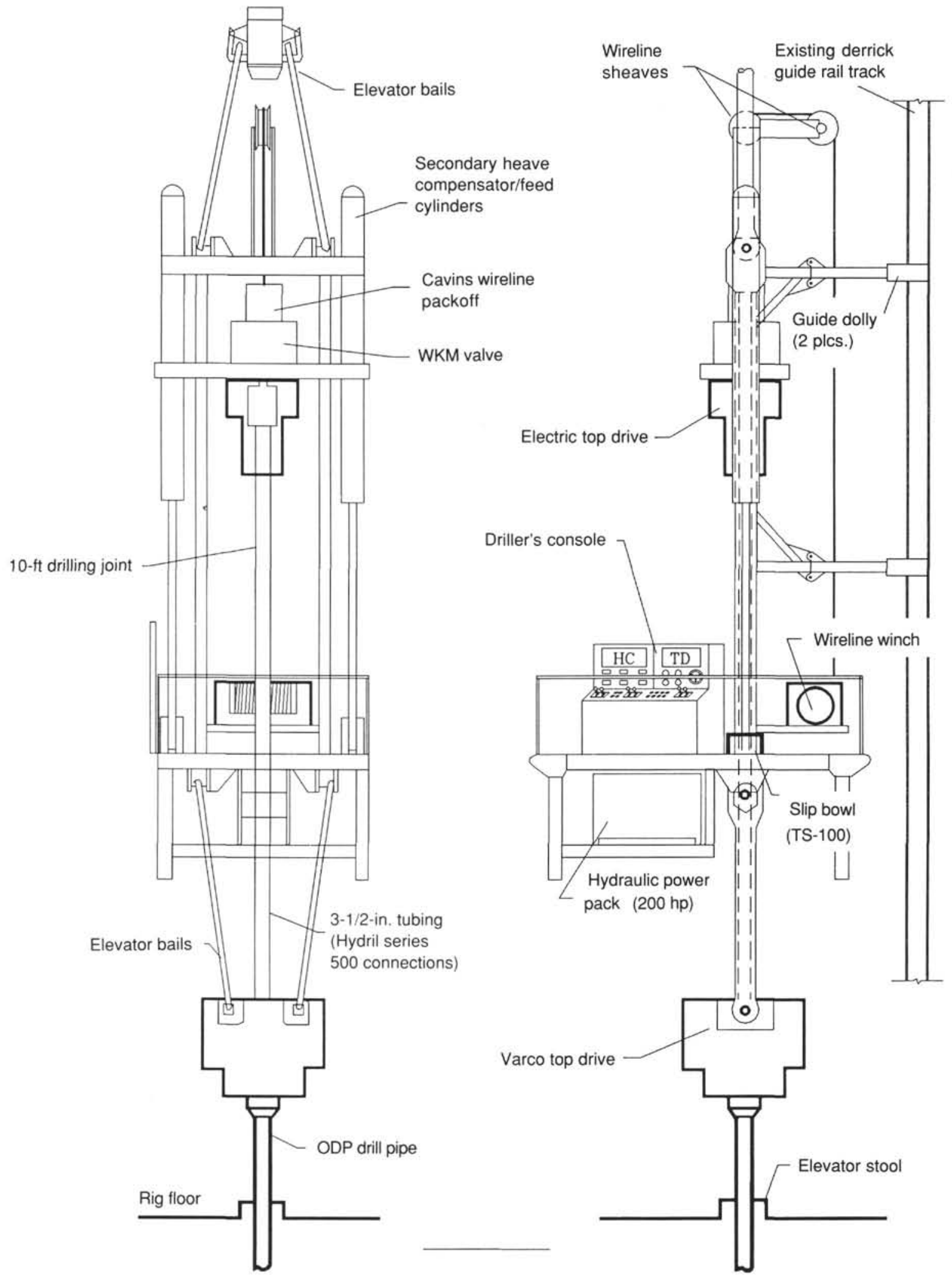

Figure 3. DCS platform configuration, Phase II (4500 m depth capacity). 
40-gallon accumulator

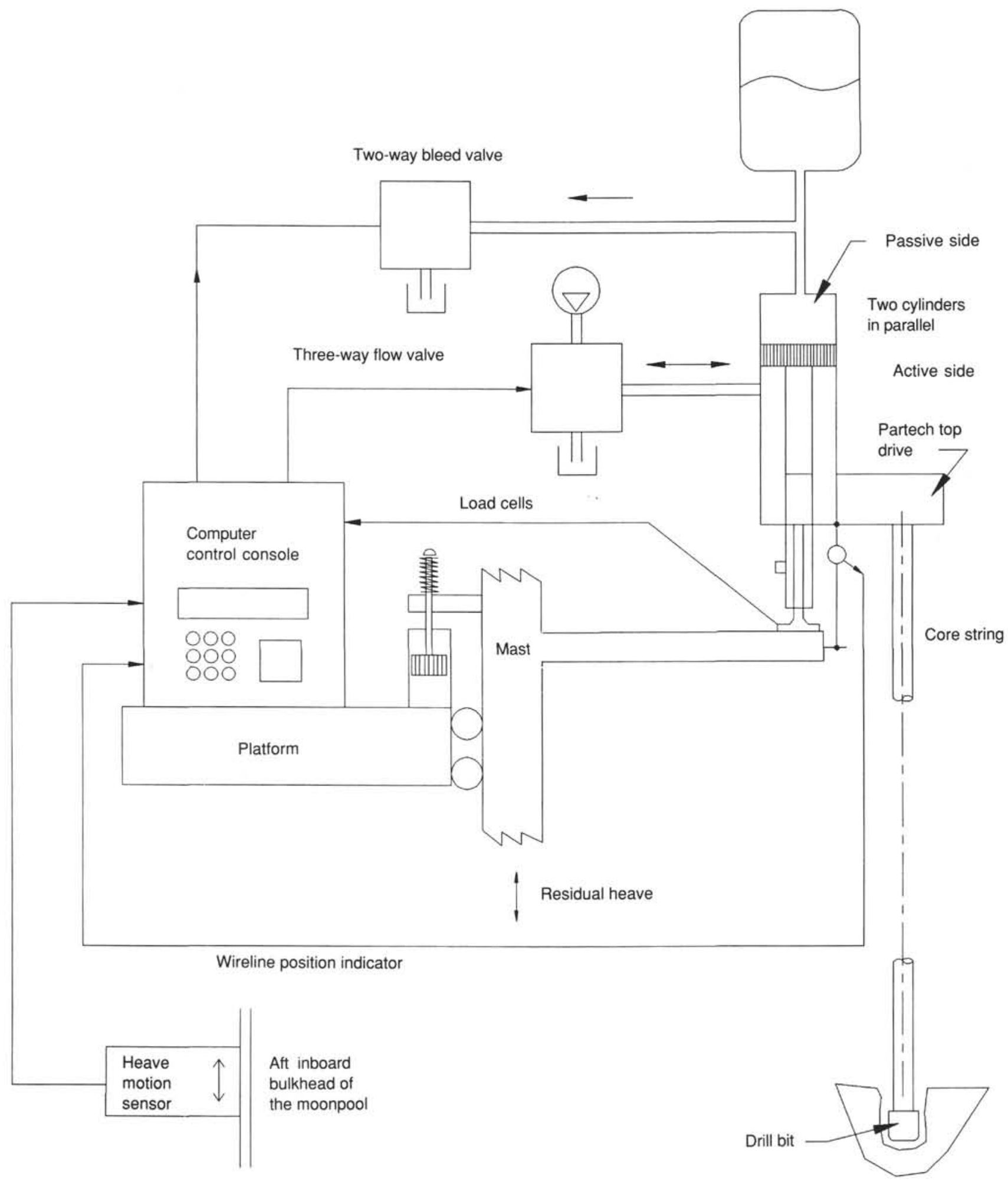

Figure 4. Basic controller physical arrangement, showing only components active in automatic mode. 


\section{Fire Suppression System and Fire Insulation}

A fire suppression system was installed beneath the main work floor of the DCS platform, directly within the hydraulic pump compartment. This system uses a high-discharge-rate dry chemical system, and is designed to discharge $25 \mathrm{lb}$ of monoammonium phosphate in approximately 10 seconds. There are four discharge nozzles aimed at the 200 -hp hydraulic power unit. The blanketing action of the system will also apply a layer of chemical on any oil in the drip pan under the pump to keep the oil from igniting. The system is controlled from the operator's console on the platform, and is manually discharged by the driller.

The work floor was insulated with a 2-in. layer of fire retardant insulation, providing further protection for personnel working on the platform in the event of a fire.

\section{Hydraulic Wireline Winch}

The hydraulic wireline winch and winch control, used for retrieving cores from the hole, were difficult to operate at slow speeds during Leg 132. A slow-speed winch control was installed to allow the wireline to be raised and lowered slowly while at the surface, when accurate control of the winch is necessary for safety reasons. Addition of the new control eliminated the previous safety hazards and any potential for dropping tools downhole.

\section{Tugger System}

The jib tugger, located on the forward side of the DCS platform during Leg 132, was relocated because of an interference problem with the primary heave compensator hoses in the derrick. This tugger was moved to the forward side of the top-drive crossmember, with a mounting arrangement designed to allow flexible positioning out over the forward edge of the platform. All existing tugger control valves were replaced with new valves for better, safer control of the tuggers, and a new control valve was added on the forward side of the platform, at the handrail, affording the tugger operator better visibility of the tugger wire and load when hoisting or lowering loads to the main rig floor.

\section{High-Pressure Filter System}

During Leg 132, hydraulic return manifold pressure at operating loads was found to occasionally exceed the pressure rating of the return filter system. This resulted in numerous cases of blown filters and the attendant loss of hydraulic oil. The original filters were rated for a maximum operating pressure of $150 \mathrm{psi}$. The filtration system was redesigned with new high-pressure filters and filter housings capable of operation at much higher pressure (350 psi).

\section{Secondary Heave Compensator}

The sensor system associated with the secondary heave compensator was changed to alleviate problems found on Leg 132. The compensator, as originally designed and used on Leg $124 \mathrm{E}$, and as intended for use on Leg 132, made use of an accelerometer mounted on the platform inside the control console. However, during Leg 132, as soon as the DCS was picked up and the main drill pipe was tensioned to the hard-rock guide base at the seafloor, the accelerometer signal was found to contain broadband noise caused by drillstring axial vibration and harmonics. This had not been the case during Leg $124 \mathrm{E}$, ostensibly because the main string was never tensioned, but instead was slacked off sufficiently to put the bottom-hole assembly (BHA) in compression. Experimentation during Leg 132 proved that the excitation of the main string was indeed causing this noise. After numerous attempts to eliminate the noise, the only viable method found was to use a ship-mounted accelerometer and a deck- to-platform displacement transducer to calculate the residual heave. The summation of the two signals was to be accomplished in a hardware circuit within the compensator panel. The summation did not work as designed; therefore, the ship accelerometer signal was used exclusively. This method worked well enough in the calm environment of Leg 132, but was still limited due to the fact that the single sensor system did not accurately describe the position or velocity of the DCS relative to the seafloor.

Changes incorporated into the Leg 142 system were intended to allow use of new sensor inputs to the computer so as to more accurately compensate for heave. A heave motion sensor (HMS) system was built. The HMS system was mounted in the vessel's mud-pit room, at the aft inboard bulkhead of the moonpool. This location is, in effect, the ship's center of pitch and roll. The second sensor, a displacement transducer, was then mounted on the traveling blocks to measure the amount of extension of the primary heave compensator rods. The HMS signal, when processed and summed in software with the displacement transducer signal, resulted in a composite velocity signal that would be used to control the servo and cancel residual (or secondary) heave (see Fig. 5).

The software was modified to accept the inputs from the two sensors, then process and combine them. Computer code was written to take the acceleration input from the HMS system, filter it, and then perform a single integration on the signal to get a velocity value. This value was then summed with the derivative of the displacement transducer input. The summation yielded a composite velocity signal.

\section{Heave Motion System}

A new accelerometer sensor package was designed and assembled before the beginning of Leg 142. This system is situated in an explosion-proof housing because of its location in the mud-pit room. The system was designed around a Sundstrand SA-700 accelerometer. The scaling of the accelerometer was set to $\pm 0.2 \mathrm{~g}$ at full scale. This signal is input to a voltage-to-current transmitter that conveys the signal to the DCS platform. This method helps to prevent interference from shipborne noise.

\section{Derrick Guide-Roller Brackets}

Wear of the derrick guide rails, noted subsequent to Leg 132, led to a redesign of the lower set of guide-roller brackets on the DCS mast. There are two sets of roller brackets attached to strongbacks on the port side of the mast. The roller brackets keep the DCS positioned over the center of the well and prevent lateral sway, as is done with the rest of the traveling equipment in the derrick. Since the center of gravity of the mast is low and to port, it was reasoned that the lower set of rollers on the DCS were much more heavily loaded than the upper set. An extra set of roller brackets (one fore, one aft) was therefore added at the bottom of the mast in order to better distribute the load by loading both sides of the inboard flange on each derrick guide-rail beam.

\section{Windwalls and Roof for DCS Rig Floor}

The DCS was outfitted with new windwalls and roofing to give protection to the drill crew in harsh weather. These were constructed of corrugated metal vs. the vinyl windwalls used on Leg 132 . The roof was also used to give added protection from falling objects that may fall from above the platform.

\section{INITIAL DCS ASSEMBLY AND TESTING DURING VALPARAISO PORT CALL}

During the port call in Valparaiso, Chile, all subsea hardware, coring and tubing hardware, and the complement of DCS machinery were loaded. The equipment and supplies were rapidly moved onto the ship. 


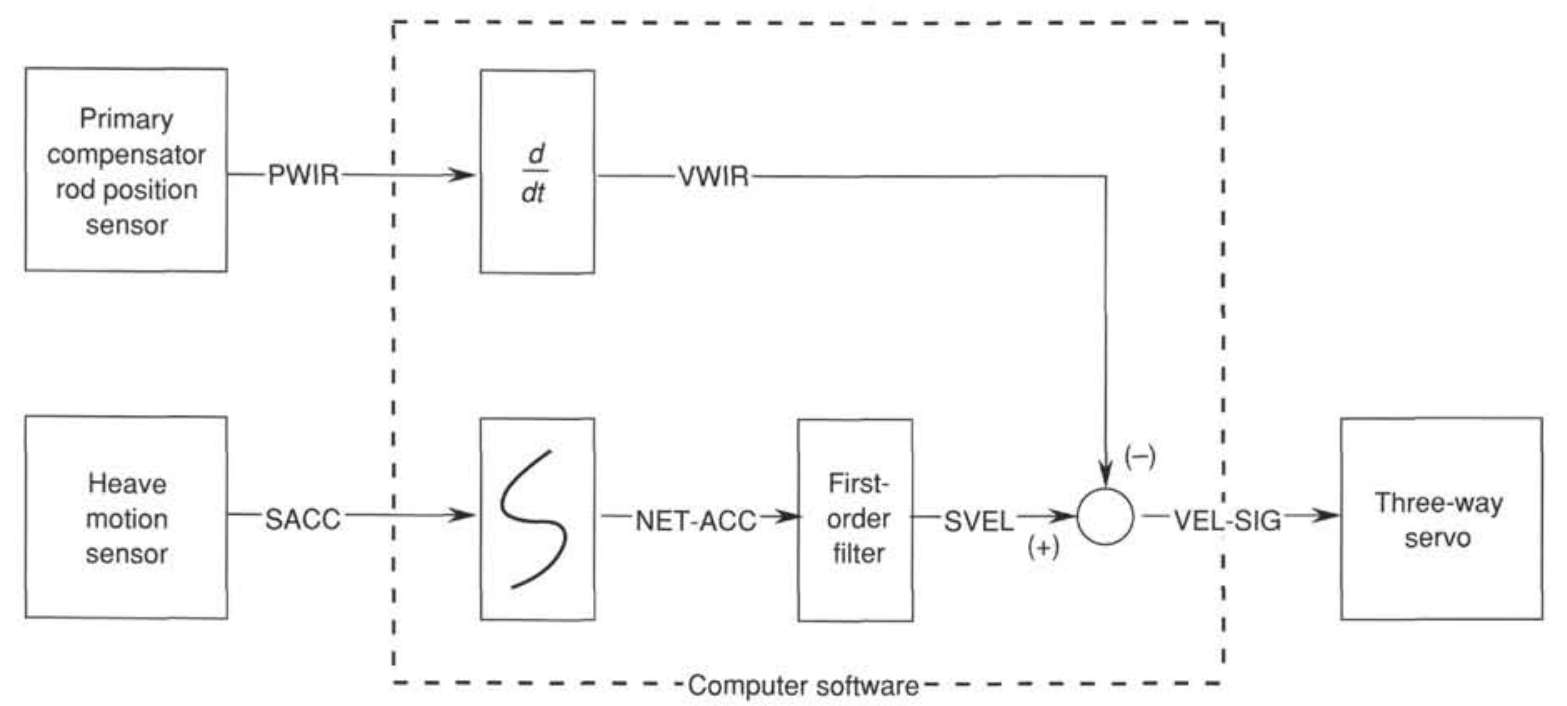

Figure 5. Secondary heave compensator control software scheme, Phase IIB. PWIR = primary compensator rod position; VWIR = primary compensator rod velocity; $\mathrm{SACC}=$ ship acceleration; NET-ACC $=$ integral of ship acceleration (ship velocity); SVEL = filtered ship velocity; VEL-SIG = velocity signal (composite control signal).

\section{DCS Mast/Platform Hardware}

The first items assembled were the dolly rails and the dolly on which the platform/mast assembly is stored. The DCS platform connects to the dolly, which is used to roll it from its storage position on the starboard side of the rig floor to its working position over the hole. The rails were centered relative to the center of the well, and steel angle cross-ties were installed to tie the rails together. Angle-iron guides were then welded to the rig floor on both sides of the rails. Next, the rails were leveled in relation to the rig floor. With the angle-iron guides to keep the rails aligned, it was much easier to lift the rails, shim them, and maintain alignment. The rails were shimmed up by using differing thicknesses of plate steel. Once leveled, the shims were welded to the drill floor.

The first piece of equipment lifted into place was the platform. The legs were pinned at the 2 - $\mathrm{ft}$ mark so that when the DCS rig was rolled out to well center, the mast would clear the Varco top drive. The mast was lifted and mated to the platform. The two hydraulic-line bundles, which were secured to the mast for transit, were fitted to the console and to the back of the platform. The mud manifold and hydraulic console drip pan were installed.

A Dreco representative assisted rig-up operations during the port call. He assisted in putting the dolly and dolly rails together. Once the platform and mast were mated, he began to hook up the hydraulic hoses. Since most of the lines had already been tagged in Houston, this portion of the work went quickly. The forward main piston valve on the rod side was leaking, and he replaced it with a new one. Once all hydraulic lines were connected, the lines were bled. This was begun by bleeding air out at the lowest points and working up the mast. The mast was raised and lowered several times to work the air to the highest point so that it could be bled from the system.

The hydraulic wireline winch (coring winch) was installed. Before operating the coring winch, the brake fluid for the Lantec brake needed to be checked. When an attempt was made to remove the top plug, it broke into several pieces. The mechanic machined a new cap, which made a good fit. However, when the coring winch was operated, the brake did not work. The master cylinder of the brake system was removed and inspected. During the inspection it was found that the plunger assembly had frozen up. The O-ring seals had deteriorated and a brake rebuild kit was installed. After the master cylinder was rebuilt, it was reinstalled. The fluid line was bled free of any trapped air. The air hose from the console was also found to be clogged. It was purged and returned to service.
The four large hydraulic hoses and the small hose umbilical on the mast were putting a bind on the mast end connections. Slack was pulled up to relieve the tension in these hoses. The splined sub on the top drive was changed out because binding in the spline mechanism showed up during tests performed in Houston. If possible, the removed sub will be refurbished. The fittings on the hydraulic tongs were changed from straights to nineties. The two main low-pressure filters for the hydraulic system were replaced. A leak was found in the 3 -in. hose leading from the reserve tank to the auxiliary pump.

Two new cylinder covers were fabricated during port call to cover the shock cylinders for the platform. The old covers did not fit. They were built to safeguard against hitting the cylinders and piping, which would cause leaks or damage. The new covers were connected to the platform by pinning them in, whereas the old covers were bolted on. A piece of 3/4-in. hydraulic hose was tied into the mud manifold to enable bleed off of manifold pressure, which could be accomplished by operating a 1 -in. valve mounted on the aft cylinder cover.

The rod basket and mouse hole were secured to the rig by bolts and a metal lip that hung over the frame of the platform. To further secure the drilling-rod basket and mouse hole and core-barrel holder, two chains were wrapped around the basket in case of a failure while the DCS rig was up in the derrick. The same was set up for the mouse hole except some aviation wire was used to tie several loops around the holder and the handrail beam.

\section{DCS Electrical System and Controls}

The control panels for the top drive and the heave compensator were unpacked and thoroughly checked in preparation for installation.

Two modifications were made to the secondary heave compensator control panel. The first modification was to the bleed-valve control circuit, as the existing control circuit did not appear to work during Leg 132. The new circuit was designed to give adequate output current to the proportional bleed valve. It also was designed with a $30-\mathrm{Hz}$ dithering signal for more consistent control of the valve. The bleed valve is used (1) whenever the computer initiates a coring sequence (i.e., enters "APPROACH" mode) and (2) when the bit is on bottom and drilling (i.e., "AUTO WOB" mode).

The second modification was to buffer the new input channels. A circuit was designed to isolate the various sensors that were added. The buffer circuit was never installed because the new software developed for use with the new sensors was never used on Leg 142. 
The top-drive control panel was installed. During the first attempt to operate the controls, several components were damaged because of land-test wiring that had not been removed prior to powering up the panel. The damaged components were replaced and operation was quickly restored. Various adjustments were then performed before the console was used for coring.

Software developed for use during Leg 132 was again used during Leg 142. New software that had been specifically intended for use on Leg 142 did not function correctly on initial trials.

\section{DCS MODIFICATIONS, ADDITIONS, AND TESTING WHILE UNDER WAY AND BEFORE DEPLOYMENT AT SITE 864}

Two problems were found in the HMS while under way to Site 864 . Testing performed before the sensor system was shipped gave good results and the system performed well on shore. However, additional modifications were made as a result of the ship's environment. The first was due to vibration in the mud-pit area. A Sallen-Key two-pole low-pass filter was designed with a cut-off frequency of 10 $\mathrm{Hz}$, which was used to keep from inducing phase shift into the signal. This circuit was tested and gave a 12-db/octave attenuation above 10 $\mathrm{Hz}$. This circuit was installed on the output of the Sundstrand accelerometer and resulted in a greatly improved signal. The second problem was a $1000-\mathrm{Hz}$ pulse found on the output of the Newport current transmitters. This transmitter is used to send the acceleration signal to the computer and is currently configured to eliminate electrical noise from shipboard equipment. The problem was first thought to be in the transmitter, so it was substituted. The same signal appeared on the next transmitter. All other systems were checked to isolate the pulse. In each check the transmitter was validated as the source of the noise. It appears that this may be a deficiency of the transmitter. However, the pulse was eliminated by installing a 1-micro-Farad (mfd) capacitor in parallel with the load. The accelerometer was calibrated for a $\pm 0.4 \mathrm{~g}$ at full-scale reading. During the leg the calibration was changed to $\pm 0.2 \mathrm{~g}$ at full scale. Since the Leg 132 software used a displacement signal and the Leg 142 software used an acceleration signal, the HMS system could only be used for the Leg 142 software because the HMS outputs an acceleration signal. An attempt was made during the middle of the leg to construct and test a circuit that would enable us to output acceleration, velocity, and displacement. Due to the short notice and uniqueness of the parts, some of the parts could not be procured before the shipping date of the Atlantis II, which rendezvoused with the JOIDES Resolution on 24 February.

Various problems with the hydraulics and safety system occurred. The safety system failed on the first attempt to pressurize it. When the forward safety cylinder was being pressurized to check the relief-valve settings, the plumbing inline with the check valve started leaking at $450 \mathrm{psi}$. The whole assembly was found to be loose. It was tightened up, repressurized, and set to $650 \mathrm{psi}$. The aft safety cylinder would not hold over 125 psi during pressurization. The check valve was disassembled and found to have been assembled backward. After polishing the face of the valve and reassembling, the system was pressurized once again. The cylinder's relief valve was set to 650 psi.

\section{DEPLOYMENT AT SITE 864}

After getting the hard-rock guide base set and a hole started, it was time to prepare to pick up the DCS rig. The 5 -in. drill pipe was run on top of the break-away safety joint. The knobbies were made up to the 5 -in. drill pipe and the assembly was jayed in, and 40,000 to $50,000 \mathrm{lb}$ of tension pulled to check the tensioning tool assembly. The drill string then was unjayed and hung off from the drill floor, just above the seafloor. Once the drill string was hung off, the regular elevator links were laid down and the tubing links were picked up.
A false floor was erected for running the tubing. The false floor consisted of four metal stands with 2 -in. $\times 12$-in. planks of wood used as the flooring. A bowl was set on top of the elevators and drill pipe. For the initial trip in the hole with the tubing, it was picked up and made up by singles. The operation started around $1100 \mathrm{hr}$ Local (L) on 12 February with the construction of the false floor and hardware. The running of the $30-\mathrm{ft}$ joints was not completed until $0130 \mathrm{~L}$ on 13 February.

A stand of four $10-\mathrm{ft}$ drilling joints was made up. After making up the joints, the false floor was rigged down. The tubing was hung off on top of the 5-1/2-in. drill pipe. The operation finished around 0230 L. The iron roughneck and elevator handler were removed from the floor. The forward port rail was reinstalled into position. The tubing links were removed and the rig's normal elevator links were reinstalled. The four inner guide rollers were reinstalled back onto the mast. The DCS rig was rolled out to well center. The lower two outer guide rollers were installed, and all the guide rollers were fitted into the guide rails.

The starboard handrail was put back in place and secured. The wind walls had to be modified due to poor fit. While the wind walls were being installed, the nitrogen system on the rig was filled up to $800 \mathrm{psi}$. After the rig system, the two platform bottles were filled up to 2000 psi.

Twenty of the 3-1/2-in. drilling joints had their box and pin connections cleaned and then measured. After measuring, the joints were picked up and lowered into the rod basket. The upper links were pinned to the mast and the wireline support was extended and pinned in.

With the first attempt to lift the system, the safety cylinders stroked out. The original setting of the relief valves was $650 \mathrm{psi}$. The system was lowered to stroke the cylinders back in and the relief valves were readjusted to $750 \mathrm{psi}$.

Due to the location of the Varco top-drive supports, the lower links were pinned in first. After pinning the links in, the DCS rig was raised $5+\mathrm{ft}$, and the level wind for the coring winch was pulled down and pinned. The coring winch was lowered into the tubing for what was estimated to be approximately $1000 \mathrm{~m}$. Except for this minor problem, no other problems were seen with the coring winch as it was lowered or brought out of the hole.

The platform was raised up into the derrick, but could only be raised to about $70 \mathrm{ft}$ because two stands of drill collars needed to be moved back and over to allow the DCS rig to get to the $90-\mathrm{ft}$ level. After moving the drill collars, the rig was brought back up and the roof top made it to within $2 \mathrm{ft}$ of the $90-\mathrm{ft}$ level. The heave compensator was tested out and it was noticed that the shock cylinders began to slowly slip open. A valve was opened to pump the cylinders closed, but instead the cylinders stroked fully open, the result of a relief-valve setting that was too low.

At this time, the heave compensator was closed and the rig brought back down to the floor. Before setting the rig down, the level wind on the coring winch had to be pulled in and tucked back under the top drive to get back down. Because the links were on, the legs were fully extended to allow the platform to rest on the dolly. At this point the system was picked up by the drawworks to get a weight of the system. The weight of the platform was measured at $24,000 \mathrm{lb}$. This time the relief valves were set to $900 \mathrm{psi}$, and this worked for the rest of the leg.

After fine-tuning the shock cylinders, the DCS was lifted back into the derrick while a knobby was set into the mouse hole. The Varco top drive was picked up with the short links. The DCS system was taken back up to the $45-\mathrm{ft}$ level where the stripover operation was to begin. A tool was built to allow the coring winch to lower and pull the tubing in the stripover operation. The tool was essentially a lifting sub with a shackle connected to a sub that screwed onto the rope socket. This tool was made up to the coring winch and lowered through the false floor of the DCS and the Varco top drive. After making up the lifting sub to the tubing, the coring winch was used to pick up the tubing and pull it back to the false floor of the DCS. The tubing was lowered to a point at which the top of the rope socket was below the top of the rotating head that was on top of the Varco top drive. A 
knobby was made up to the Varco top drive and was positioned back over the 5-1/2-in. drill pipe. The tubing was pulled back up, and then set in the slips and made up to the DCS top drive. The tubing was lowered until the connection was made with the tubing stub left above the drill pipe. At this time the tubing was made up and the DCS top drive picked up the weight of the tubing string. The knobby was lowered and it was made up to the 5-1/2-in. drill pipe.

The reentry assembly had a stinger assembly on it that was 7.64 $\mathrm{m}$ long. Due to the length of the stinger, the guide base had to be reentered before more pipe could be added. At this time the primary heave compensator was opened and the guide base was reentered. After reentering, the heave compensation was turned off in order to add another knobby. The knobby-Varco top drive connection was broken. The bowl and slips were set on the tubing and the tubing connection was broken. The tubing connection and the DCS top drive connection was broken and the coring winch connection made up. Again, the rope socket was lowered until it was a couple of feet below the top of the rotating head. The Varco top drive was tilted over and another knobby was made up. While pulling the knobby out of the mouse hole, the tubing became stuck below the knobby. The coring winch line parted at approximately $13,000 \mathrm{lb}$ of pull, and the three joints of $10-\mathrm{ft} 3-1 / 2$-in. tubing were dropped through the mouse hole and lost. The broken wireline was pulled up and lowered to the rig floor. A new rope socket was poured. At this point the tubing was pulled out of the rod basket and made up and run down to the tubing stub above the first knobby. The tubing run from the DCS platform was made up to the tubing that was hanging off, and the DCS top drive picked up the weight of the tubing string once again. The second knobby was lowered and made up to the first.

The compensator was opened again, and the whole tensioning assembly was lowered down into the hole. After circulating out the fill, the tensioning tool was jayed-in and 40 to 50 kips of tension pulled against the guide base.

\section{Bit Run Number 1}

The BHA used was a Longyear modified HQ- 3 core-barrel assembly consisting of a Longyear Series 2 impregnated coring bit, lower reaming shell, outer barrel, and a locking coupling. Added to the coupling was a crossover from the modified Longyear thread to the DCS drill string of Hydril Series 501 threads.

A variety of tests were performed with the inner barrel out and with the inner barrel in. The inner barrel was retrieved after the last flow test. The bypass valve on the floor was left open during the retrieval process. This allowed a greater swabbing effect and pulled loose formation and cuttings into the hole. After pulling out the barrel, the pipe was reconnected and heavy (12 lb/gal) mud was pumped. Only a small amount of mud was pumped when the pressure increased to $1500 \mathrm{psi}$. The pressure was built up to a maximum of $2200 \mathrm{psi}$ and correspondingly bled off to zero. It was decided to run the inner barrel down on the wireline to check whether any fill had come into the tubing. After running $800 \mathrm{~m}$ down, the core barrel was overrun by the winch line. This caused the winch line to kink and wrap on itself. The wireline was straightened out and respooled. The core barrel was retrieved and the bad wireline spooled off and cut. Another rope socket was poured.

Circulation could not be achieved out of the 5-in. drill string. Instead, circulation was established around the tubing and back to the ship. An attempt was made to work the tension tool in the jay slots. The tool would not move in the slots. Up to $15,000 \mathrm{lb}$ was put on the tensioning assembly, but the tapered stress joint started bending. Baravis with a viscosity of 34 to 36 seconds was pumped down the tubing to fill it and the annulus. The center bit was pumped down, and the tubing was lowered down. Approximately $9 \mathrm{~m}$ of fill was tagged. Fill was approximately as high as $0.8 \mathrm{~m}$ above the seafloor.

Initially, the fill was cleaned out using the secondary heave compensator. Circulation was broken through to the seafloor, which caused problems for the heave compensator computer. Before circulation broke through to the seafloor, it was taking about $9000 \mathrm{lb}$ of weight to clean out the fill. To check the pump off, the weight was backed off until no progress was being made. This pump-off was around $4700 \mathrm{lb}$. Once circulation was broken through, the dialed-in weight on bit (WOB) used was 2500 to $3500 \mathrm{lb}$. Before a connection was made, the tubing was pulled back up and lowered back through the same interval. This was performed as a precautionary reaming and to check whether more fill was falling in. Because the circulation would come and go from the ship to the seafloor, it was decided to use a manual feed without heave compensation. The pipe was worked down to where bottom was anticipated when the pipe came out into a void. The tubing was pulled back up two joints and the center bit was retrieved. The center bit showed minimal wear, so it was thought that the bit was still in good shape.

A core tube was dropped and coring operations began. The WOB control portion of the heave compensator was erratic, with changes of 1300 to $3400 \mathrm{lb}$, although pump pressure at this time was stable. After coring for $38 \mathrm{~min}$, rotation was stopped and WOB control underwent some work since it seemed the advancement was too slow. The heave compensator and WOB control was checked while on bottom. Several times the bit was placed on bottom and coring attempted, but was pulled off bottom when it was felt the system was not responding properly. During this time, the pump pressure jumped up to over $3000 \mathrm{psi}$. Every time the pump was put on line, the pressure would build up. One joint was put back in the basket and the coring winch was run to retrieve the inner tube. The first pull went to 7000 lb. The jars were used twice and the inner tube pulled free on the second use of the jars. When the tube was retrieved, it showed 1/4-in. wear on the core catcher. Indications were that the bit was destroyed.

Since the bit was appeared to be destroyed, it was decided to work on the heave compensation system. The center bit was pumped down and latched into place. After the heave compensation system was worked on and tested, the center bit was pulled out. Circulation was continued at all times. No jarring was needed to pull the center bit out. Three 10 -ft drilling joints were pulled in preparation for the stripover operation. A successful attempt was made to unjay from the hard-rock guide base. The stripover operation began and three more joints were pulled out after the 30 -ft knobby connection was broken. The rest of the joints were lowered using the rope socket, so the Varco top drive could be tilted and the $30-\mathrm{ft}$ knobby placed in the mouse hole. The joints were brought back up and made up to the DCS top drive. The platform was lowered and made back up to the rest of the pipe. The platform was raised and the lowermost knobby broken. In looking for a tool joint one of the joints taken out had to be added back to the string. Seventeen $10-\mathrm{ft}$ drilling joints were left in the rod basket. The rest of the drilling rods were lowered by the coring winch. Five $10-\mathrm{ft}$ drilling joints were laid out. The two 20 - $\mathrm{ft}$ knobbies were laid out and the platform lowered. The top drive was swung back and secured. The platform was brought down to the point where the DCS top drive was set up on its extended stops. The unjaying and stripover operation took from 0400 to $0700 \mathrm{~L}$.

The coring winch level-wind compensator was unpinned and swung and tucked back under the DCS top drive. The links were removed and the platform lowered. The dolly was rolled out over well center and the platform legs were repinned to their 2 -ft level. The roller brackets were disengaged from the derrick guide rails and swung back out of the way. The two lower outer rollers were removed at this time. The wind walls and roof were removed along with the starboard handrail. The coring winch brace was unpinned and retracted to its lower position. The top links were unpinned and the traveling equipment picked up. The DCS was rolled back into its transitting position and secured. The rigging down took from 0700 to $1045 \mathrm{~L}$.

The false floor and associated hardware for tripping the tubing out of the hole were reassembled. The tubing was pulled out of the hole and racked back in 90 -ft stands. 


\section{Bit Run Number 2}

The BHA used was a Longyear modified HQ-3 core-barrel assembly consisting of a Hobic Series 1 impregnated coring bit, lower reaming shell, outer barrel, and a locking coupling with a crossover from the modified Longyear thread to the DCS drill string of Hydril Series 501 threads.

Some minor modifications were made while the second drill-in BHA was being set:

1. A jumper hose was made to connect the pump to the oil saver. This was done in an attempt to halve the number of trips climbing up the mast to connect and disconnect the hose fitting. Unfortunately, this feature had to be removed as it proved to cause problems. The hose hanging from the oil saver got caught in the top drive while it was up. When the drive was brought down, it pulled and stretched the hose.

2. A short section of portable ladder was added to aid in climbing up the mast. Depending on the space-out, there were times when the mast would be in a higher than normal position, and the need would arise to climb the mast. This ladder made it easier to climb up the mast-a safety feature.

3. A guard was welded on to the bottom of the forward tugger to stop the potential of the wire rope from coming off of the reel.

4. A funnel was built and welded in place to aid in putting the oil saver and jars back up in the scoping brace. The funnel idea was to give the oil saver a smooth surface to glide against instead of coming up against a square shoulder. The only problem was that the funnel did not cover up the square shoulder as it was intended. The funnel helped, but the square shoulder still caused some delays in pulling the oil saver back into the brace.

After the tubing stripover operation, Baravis was circulated down the drill pipe-tubing annulus. The pressure built up to $1300 \mathrm{psi}$ and blew around the rotating head rubber. The rotating-head rubber was replaced and pump pressure was kept to a maximum of $500 \mathrm{psi}$. After the Baravis was circulated down the annulus, the tubing was rotated, and vibration and torque were noticed. The mud pit from which the Baravis had been pumped was investigated and found to be contaminated. A new batch of Baravis was made up and pumped down the annulus, displacing the old mud. In the mean time the tubing was filled with Baravis. After the contaminated mud was displaced from the annulus, the vibration and torque continued. As a result, we elected to go with $60 \mathrm{bbl}$ of seawater and Baravis mixed with $15 \mathrm{gal}$ of EP Mudlube. The bit deplugger was pumped down to assist in guiding the tubing into stub of second drill-in BHA. The EP Mudlube was pumped down the annulus, starting at a rate of 11 strokes per minute (spm) at $500 \mathrm{psi}$ and finishing at $4 \mathrm{spm}$ at $500 \mathrm{psi}$. While the Mudlube was just beginning to be pumped, the tubing string was lowered. No vibration or torque was seen afterward. The tubing was lowered until the bit was approximately half a joint off bottom. The bit deplugger was pulled and the inner tube dropped for coring operations.

During this time coring was started. The first advance was used to identify and tag bottom. The secondary heave compensator variables were changed to optimize the standby mode. The movement of the pipe appeared to be correct so the compensator was put into AUTO WOB mode. As soon as the AUTO WOB sequence began, the system started to oscillate. At this time the parameters were changed and the system performed better. With these new parameters, coring was continued and advancing began. There was a considerable amount of motion on the bit, which was observed as variation in the torque and $\mathrm{rpm}$. The hole was advanced approximately $.3 \mathrm{~m}$, then seemed to stop advancing. This indicated the core tube was blocked off. After evaluating the conditions, the core tube was retrieved to the surface.

After retrieving the core tube with some apparent core, the tube was redressed and dropped. The circulating mud was very thick; the viscosity was checked and appeared to be 60 seconds, but the mud that came out on connections was much thicker. Therefore, we continued to try to circulate a lower viscosity mud. Some vibration was occurring, with the drill string rotating over $120 \mathrm{rpm}$. Coring was attempted several times. While coring, the torque would show the bit to be on bottom, but then it would drop down to $500 \mathrm{ft}-\mathrm{lb}$ from a reading of 1000 to $1500 \mathrm{ft}-\mathrm{lb}$. A few times the torque stayed somewhat steady and the consensus was that the bit was on bottom, coring. During this time we stopped the operation frequently to make adjustments to the secondary heave compensator. Finally, the coring operation was stopped to check on some problems.

The heave compensator was tested and it was observed that the stroke against the accumulators was inadequate. The nitrogen system was found to have leaks unable to maintain pressure in the top end of the accumulators. The hose between the tee fitting and the lower aft bottle was found to be defective. After this was replaced, a leak check of the system was performed. Another hose was found to be defective between the upper and lower aft bottles. The hose and a valve on the lower bottle were replaced at this time. The system was checked once more. This time the bottles were charged to $1100 \mathrm{psi}$.

Again during the testing of the heave compensator, the system appeared to be leaking from the rod side. The only component that was suspect was the tripping valve. The valve was removed and after analyzing it, we found that it was hooked up wrong. A new valve was installed. With the new valve and plumbing corrections the leaking was prevented and the tripping function was restored.

When drilling resumed after the testing, all indications suggested that the bit was gone or no good. The platform was prepared in order to begin pulling out of the hole. With the 10th joint in the hole, approximately halfway up on it, the BHA or bit pulled up against something. There was no weight indication. It pulled and slipped off hard enough to jerk the mast up and stroke out 6 to 8 in. on the shock cylinders. The tubing was lowered less than a meter and pulled back up very slowly. Again, nothing was seen, so pulling the drilling joints for unjaying and stripping over was continued. The tubing and annulus were flushed with seawater. The unjaying operation went smoothly. Two more 10 - $\mathrm{ft}$ drilling joints were pulled during the stripover operation.

While lowering the platform, a mental lapse occurred. Concentration was on the links, and the coring winch level-wind compensator was forgotten. It hit the top drive supports and bent the carriage support. The platform was picked back up, and the level wind tucked back under the DCS top drive. The rest of the rigdown went smoothly. The platform was rigged down and rolled back out of the way. The false floor and hardware were rigged up to pull the tubing out of the hole.

\section{Bit Run Number 3}

The BHA used was a Longyear modified HQ-3 core-barrel assembly consisting of a Hobic Series 2 impregnated coring bit, lower reaming shell, outer barrel, and a locking coupling, with a crossover from the modified Longyear thread to the DCS drill string of Hydril Series 501 threads.

Because the cantilevered piece on the coring winch (level-wind compensator) was hit, a new 4 -in. ${ }^{2}$ tube was welded to replace the piece that was bent. We could see from looking at the piece cut off that most of the stress was taken by the L-bracket which had been welded on. Replacing the square tube was better than taking a risk on damaging the coring winch bearings. After rolling the platform out to well center, the coring line was run down to $1000 \mathrm{~m}$ and proved to be in good working order. The stripover operation began and the hardrock guide base was reentered. The tensioning tool was jayed back in and 40 to 50 kips were pulled on the drill string. Two $10-\mathrm{ft}$ drilling joints were run and then the center bit was dropped down the tubing and latched in place. A series of test on the heave compensator were conducted. Test results are reviewed in the "Heave Compensator Performance" section (this chapter). 
The tubing was worked down with the center bit in place. The hole was cleaned out to within half a joint of bottom. It was thought that the DCS was ready to core. The center bit was pulled but the jars had to be used to recover the center bit. The center bit came out with the crown of the bit missing. When the center bit was broken off, the middle plug of the center bit with the water courses was found on the inside of bit. The center bit had been totally welded up. The tubing was pulled in preparation for unjaying and the stripover operation. There were no problems coming out of the hole. The tubing and annulus were flushed with seawater. Again, the unjaying operation went smoothly and the stripover operation continued. The stripover operation went flawlessly.

The rigdown also went smoothly. Special attention was paid to the coring winch, and the level wind was unpinned and tucked back under the DCS top drive. The DCS platform was rolled back and secured in place. The false floor and hardware were rigged up to pull the tubing out of the hole.

\section{Heave Compensator Performance}

All tests were conducted using the Shaevitz Heave Motion Sensor as input, which is a displacement signal. The system was operated in the same configuration as during Leg 132. The compensator operated in standby mode relatively well. An accelerometer was installed on the drill pipe to test and to adjust keyboard parameters for best compensation. The maximum measured acceleration was measured at $.035 \mathrm{~g}$, and this was attributed to seal friction and stiction. At this level the bit should not leave bottom once weight is applied.

The next series of tests was conducted owing to an observed problem. The weight would fluctuate as the top drive moved from point to point in the mast. There are two load cells, one under each feed cylinder. These were isolated one by one and tension tests were run. It was found that the forward load cell was varying over $5000 \mathrm{lb}$. When trying to maintain a constant weight on bit of less than $2000 \mathrm{lb}$, the system could not use the load cell. A quick fix of the problem was to edit the program. The routine for WOB was changed to disregard the forward load cell and multiply the aft by a factor of two.

With the drill-pipe acceleration and load-cell tests completed, we conclude that the load cell played a big part of the problem. To compound the problem, the forward cylinder appeared to be bent, which would put excess force on the load cell.

\section{EVALUATION OF DCS COMPONENTS}

\section{Shock Cylinder System}

The shock cylinder system performed well. The system at first had to be rebuilt due to problems caused during final assembly. It was adjusted to specification and operated for the duration of the deployment. The system had an unscheduled test because the drill tubing got stuck in the API string. Due to the load-cell problem, discussed in the previous section, the driller was unaware of the overpull that was being applied to the tubing. When the tubing worked loose, the force was great enough to cause motion on the platform, thus extending the cylinders.

\section{Fire Suppression System and Fire Insulation}

Fortunately, this system did not have to be used. Its performance could not be evaluated based on an actual fire. However, the system was discharged and the monoammonium phosphate was distributed to all areas that it was designed to cover. The total discharge time was around 10 seconds.

\section{Hydraulic Wireline Winch}

The modification to the speed control on the winch functioned very well. The slow speed functioned without any problems and greatly improved overrun problems experienced on Leg 132 . When switching from slow speed control to high speed, which is used for running in the hole and pulling out, care must be used. Due to the resistance caused by the fluid in the pipe against the light weight of the running tools, a sufficient amount of cable has to be payed out before the winch can be run at top speed.

The fleet angle compensator used for the winch level wind functioned about $90 \%$ of the time. The counterbalance had to be manually positioned when the line reached the aft side of the spool. This appeared to be caused by the compensator being out of adjustment. Due to the complexity of this adjustment, it was not performed by the crew. Before the next DCS deployment, the factory representative will adjust it and will also instruct ODP personnel on the procedure.

Prior to the first deployment of the DCS, the brake malfunctioned. The seals in the brake cylinder had deteriorated, causing the plunger to stick. Rebuilding the cylinder will become a normal maintenance item before deployment.

\section{Tugger System}

The tugger modifications performed very well. The position of the forward tugger control will have to be changed. When the pipe basket was mounted on the rig, it obstructed the view of the operator. This made it necessary for two people to deploy and retrieve equipment from the drill floor.

Due to the angle at which the tugger cables are run at times, guards were placed on them to prevent the cable from jumping off the reels.

\section{High-Pressure Filter System}

The filtration system performed very well. None of the problems encountered on Leg 132 reappeared.

\section{Derrick Guide-Roller Brackets}

The guide-roller brackets performed very well. No problems with broken rollers as were encountered on Leg 132 appeared during Leg 142. The guide rails were not checked for wear, so it is not known at this time if the bracket modification solved the problem of excess rail wear.

\section{Windwalls and Roof for DCS Rig Floor}

The windwalls and roof worked well in adding more protection from the elements. However, both the windwalls and roof will need to be modified due to the difficulty in installing them on the DCS.

\section{Secondary Heave Compensator}

The secondary heave compensator is not easy to evaluate at this time. It appeared not to work at all, so we will need to conduct a study after the system is returned to shore. Several possible causes will be investigated.

The first concern is a bent feed cylinder on the forward side of the rig. If this cylinder has an excess amount of drag associated with it, the load cell that the computer uses for the weight-on-bit mode will give bad data. Even if the computer was operating correctly, the output would represent the bad input; hence, "garbage in, garbage out."

The second concern is the software in the controller. Various versions of software were installed and all reacted differently. The software that was used successfully during Leg 132 did not control the system as before. This could be due to the differences in the weight of the drill string and weather conditions between the two legs. This will also be evaluated at a later date.

\section{RECOMMENDED DESIGN MODIFICATIONS AND IMPROVEMENTS}

The following is a list of the recommended design modifications and improvements to the diamond coring system: 
1. Do a complete evaluation on the secondary heave compensator. The points to stress are the capabilities of the present system. Will it be able to operate to the original designed depth of $4500 \mathrm{~m}$ ? The software will need to be analyzed and preferably modeled to get an idea of its deficiencies. This would best be done by an outside source in order to get a fresh look at the problem.

2. Modify the heave compensator controls to allow manual drilling. The system has the capability to do this; however, the software will have to be modified to allow it.

3. Modify the accelerometer system to enable it to output acceleration, velocity, and displacement. In addition, the modification will also be used to slave the signals to a zero offset. These offsets have been caused by both temperature changes and tidal changes. Since these changes are of long duration the washout circuit's time constant also will have a long duration.

4. Modify the piston-side bleed-valve plumbing to ensure the bleed sequence can be performed correctly.

5. Modify the load-cell system with hydraulic load cells. This will enable a large weight indicator to be installed. It will also add dampening for the computer load-cell channels, and will give the rods a bigger surface to compress and to allow movement in the lower rod ends.

6. Modify the feed cylinders to disable the test cylinders. These were used to do heave test on land and have proved to be ineffective. Eliminating them will give us a solid surface on which to work with the load cells.

7. Inspect and replace the forward feed cylinder. This cylinder is suspected of being bent. If this is the case, we need to provide better support to the cylinder so it will not bend again (i.e., roller brackets)

8 . Conduct full-scale load testing of the entire DCS platform to $150,000 \mathrm{lb}$, with heave induced in some method other than with test cylinders.

9. Add redundancy to as many of the critical sensors as possible.

10. Add a data recording system for drilling parameters.

11. Separate the mini-umbilical from the platform jay-box. Install plugs and connectors on the jay-box and cable ends.

12. Install plugs and connectors on the heave compensator control panel and associated cabling. This will ensure environmental integrity and will aid in console installation.

13. Clean up hydraulic console. Install hard piping where hoses are used. Replace all damaged wiring within console.

14. Inspect and replace corroded hose fittings throughout the platform.

15. Add blower on/off switch for the top drive on the hydraulic console. The space taken by the spooling arm can be used.
16. Add a set of indicator lights on the control console in close proximity to the WKM (WKM Industries) valve control to positively indicate when the valve is in the "open" or "closed" position.

17. Modify current load-cell cups to accommodate new load cells when selected. The new cups will need to be better supported than the current arrangement in order to avoid sagging under load.

18. Modify guide-roller brackets so that they can be swung completely back against the mast strongbacks.

19. Add a mud-pump ammeter to top-drive control panel, spare wires permitting.

20. Add buffer to the strokes-per-minute signal in the top-drive control panel. Fix negative sign on display.

21. Design and install an angled instrument cluster above the electronic consoles for large gages. This should include mud pressure, string weight, wireline weight, and possibly top-drive torque.

22. Lower mast stops, if possible, to increase head room.

23. Clean up shock cylinder tubing and hoses.

24. Clean up structure surrounding mast sockets on platform.

25 . Add pins or blocks on core winch to allow installation.

26. Add cradles for top pins on mast crossmember so that pins can be left in place.

27. Modify umbilical hanger brackets for derrick so umbilicals can be pinned in place, as opposed to requiring bolts in shear.

28. Conduct nondestructive testing of mast from top to bottom at all critical load points.

29. Rework roof panel of windwall system.

30. Straighten handrails and sockets. Rebuild if necessary.

31. After all work is performed, conduct an inspection of all modifications to ensure that all assemblies mate together correctly. As the system is being rigged down it should be thoroughly cleaned, sandblasted, and painted.

\section{REFERENCES*}

Harding, B.W., Storms, M.A., et al., 1990. Proc. ODP, Init. Repts., 124E: College Station, TX (Ocean Drilling Program).

Storms, M.A., Natland, J.H., et al., 1991. Proc. ODP, Init. Repts., 132: College Station, TX (Ocean Drilling Program).

* Abbreviations for names of organizations and publication titles in ODP reference lists follow the style given in Chemical Abstracts Service Source Index (published by American Chemical Society).

Ms 142IR-107 